\title{
Antiretroviral therapy-induced lipodystrophy
}

\author{
Vineet Behera, ${ }^{1}$ Makarand Randive, ${ }^{2}$ Sambit Sundaray, ${ }^{2}$ M S N Murty ${ }^{3}$
}

${ }^{1}$ Department of Internal Medicine, Armed Forces Medical College, Pune, Maharashtra, India

${ }^{2}$ Department of Medicine, Armed Forces Medical College, Pune, Maharashtra, India ${ }^{3}$ INHS Asvini, Mumbai, Maharashtra, India

\section{Correspondence to} Dr Vineet Behera, beheravineet@gmail.com

Accepted 20 January 2015

CrossMark

\section{To cite: Behera V} Randive M, Sundaray $S$ et al. BMJ Case Rep Published online: [please include Day Month Year] doi:10.1136/bcr-2014207090

\section{DESCRIPTION}

A 55-year-old man was detected with pulmonary tuberculosis 5 years earlier and was also detected to be HIV positive with a CD4 count of $362 / \mathrm{mm}^{3}$. A course of antitubercular therapy (oral isoniazid $300 \mathrm{mg}$ once daily, rifampicin $600 \mathrm{mg}$ once daily, ethambutol $1000 \mathrm{mg}$ once daily and pyrazinamide $1500 \mathrm{mg}$ once daily) was given for 6 months and the patient was cured of tuberculosis. The patient was started on antiretroviral therapy (ART) comprising of zidovudine, lamivudine and nevirapine. Over the next 2 years, the course was uneventful but there was progressive decline in $\mathrm{CD} 4$ count and increase in HIV viral load. In view of immunological and virological failure, second line ART was started 3 years ago (zidovudine $300 \mathrm{mg}$ twice daily, tenofovir $300 \mathrm{mg}$ once daily, lopinavir/ritonavir 400/100 mg twice daily).

After about a year of changing ART, the patient developed hollowing of cheeks, loss of orbital fat (figure 1), temporal wasting (figure 2) and truncal obesity. Investigations showed impaired fasting glucose, hypertriglyceridaemia and hypercholesterolaemia. Other endocrine and metabolic workup, and remaining investigations, were normal. A possibility of ART-induced lipodystrophy was considered.

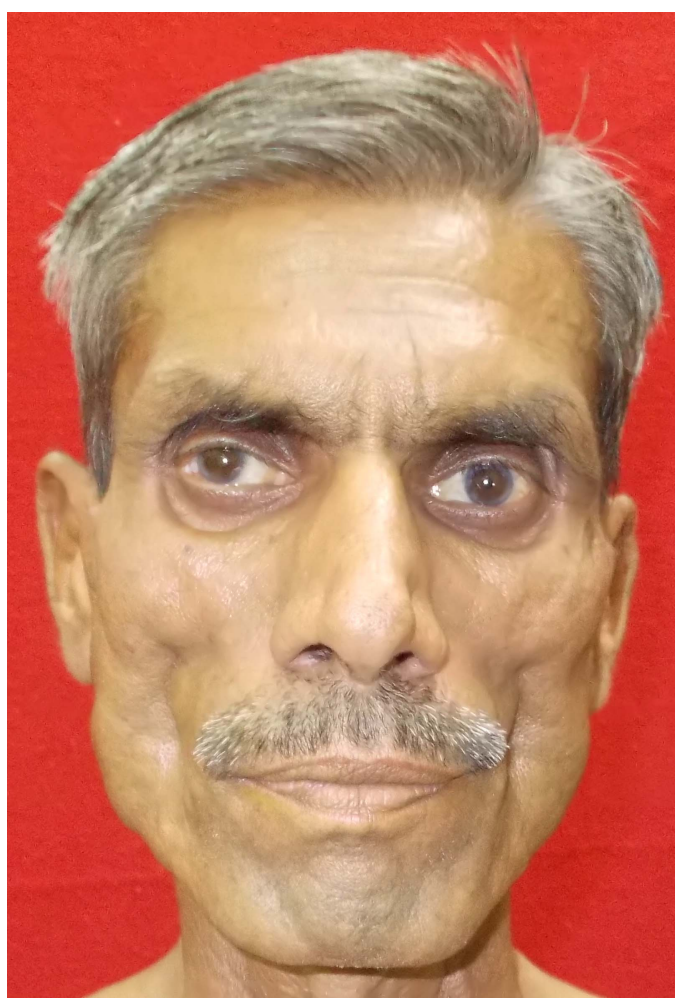

Figure 1 Showing hollowing of cheeks and loss of orbital fat.

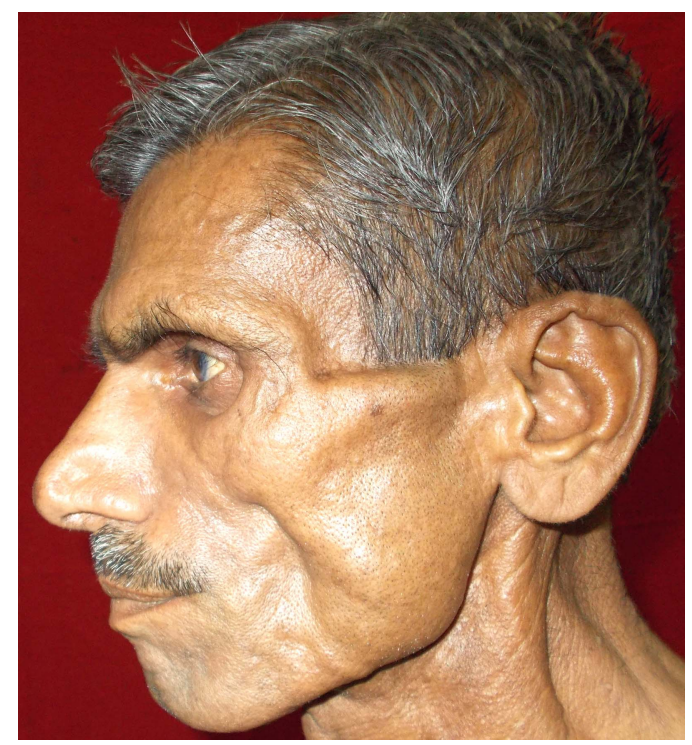

Figure 2 Showing temporal wasting.

The patient was advised lifestyle modification, and started on atorvastatin and metformin; zidovudine and lopinavir were changed to abacavir and saquinavir, respectively.

ART-induced lipid disorders include lipoatrophy, which is characterised by selective loss of peripheral adipose tissue from sites such as the face, temporal scalp and buttocks; and lipodystrophy, which is abnormal deposition of this fat at central sites including the trunk and dorsocervical spine, or viscerally in muscles and liver. This commonly occurs with zidovudine, didanosine, stavudine and most protease inhibitors (PIs). ${ }^{1}$

The pathogenesis of adipose cell dysfunction is not clear. Nucleotide reverse transcriptase inhibitors cause lipolysis by inducing mitochondrial dysfunction, and modifying adipocyte phenotype and pattern, by secretion of cytokines and production of reactive oxygen species. PIs may induce lipoatrophy by inhibiting sterol regulatory enhancer-binding protein and peroxisome proliferator-activated receptor, which are involved in lipogenesis. They also inhibit lipogenesis and adipocyte differentiation and stimulate lipolysis. ${ }^{2}$ This may be associated with metabolic abnormalities such as dyslipidaemia, impaired fasting glucose or insulin resistance, and may lead to atherosclerosis and coronary artery disease. A high index of suspicion is required along with regular monitoring when caring for patients on ART. The treatment of lipodystrophy is difficult and includes lifestyle modifications, switching to nonlipodystrophic ART, statins, fibrates, metformin, thiazolidinediones and growth hormone. ${ }^{3}$ 


\section{Learning points}

- Antiretroviral therapy-induced lipoatrophy is characterised by selective loss of peripheral adipose tissue from sites such as the face and temporal scalp; and lipodystrophy, which is abnormal deposition of this fat at central sites such as cervicodorsal; or visceral fat.

- It is associated with metabolic abnormalities such as dyslipidaemia, impaired fasting glucose or insulin resistance, which may lead to atherosclerotic disorders.

- This commonly occurs with zidovudine, didanosine, stavudine and most protease inhibitors.
Competing interests None.

Patient consent Obtained.

Provenance and peer review Not commissioned; externally peer reviewed.

\section{REFERENCES}

1 Villarroya F, Domingo P, Giralt M. Drug-induced lipotoxicity: lipodystrophy associated with HIV-1 infection and antiretroviral treatment. Biochim Biophys Acta 2010:1801:392-9.

2 Grinspoon S, Carr A. Cardiovascular risk and body-fat abnormalities in HIV-infected adults. N Engl J Med 2005;352:48-62.

3 Anuurad E, Semrad A, Berglund L. Human immunodeficiency virus and highly active antiretroviral therapy-associated metabolic disorders and risk factors for cardiovascular disease. Metab Syndr Relat Disord 2009;7:401-10.

Copyright 2015 BMJ Publishing Group. All rights reserved. For permission to reuse any of this content visit http://group.bmj.com/group/rights-licensing/permissions.

BMJ Case Report Fellows may re-use this article for personal use and teaching without any further permission.

Become a Fellow of BMJ Case Reports today and you can:

- Submit as many cases as you like

- Enjoy fast sympathetic peer review and rapid publication of accepted articles

- Access all the published articles

- Re-use any of the published material for personal use and teaching without further permission

For information on Institutional Fellowships contact consortiasales@bmjgroup.com

Visit casereports.bmj.com for more articles like this and to become a Fellow 